\title{
Pair check (pc) modelling with worksheet participants media in the training of writing class action research (PTK)
}

\author{
Syahrul, R., \\ Universitas Negeri Padang \\ Elfia Sukma, \\ Universitas Negeri Padang \\ Utami Dewi Pramesti*), \\ Universitas Negeri Padang \\ *) Correspondences author: Jl. Prof. Dr. Hamka, Air Tawar Timur, Kecamatan padang Utara, Kota Padang; Indonesia \\ e-mail: utamidewi@unp.ac.id
}

\begin{abstract}
This article describes the results and the implementation of the paircheck method with a work sheet of participants which is the result of community service with the title "Training of Scientific Writing for Teachers of SD Tawar Timur Kota Padang West Sumatra." In the process, teachers are guided in writing classroom action research through a participant's worksheet that contains a summary of materials and direct exercise columns with a paired check table. Participants in this training are 26 teachers from 3 public elementary schools in East Tawar area, Padang City. The method used is qualitative-descriptive that explains the final outcome and the implementation of the training. After three days of training, the participants' writing skills increased, which was proved by pre-test and post-test.
\end{abstract}

Key Words: pair check method (Pc); participant worksheet; Classroom Action Research (PTK).

Article History: Received: 22/06/2018; Revised: 25/07/2018; Accepted: 09/08/2018; Published: 22/08/2018

How to Cite (MLA 7th): R., Syahrul, Elfia Sukma, dan Utami Dewi Pramesti. "Pair check (pc) modelling with worksheet participants media in the training of writing class action research (PTK)". Hortatori Jurnal Pendidikan Bahasa dan Sastra Indonesia 2.1 (2018): 37-45. Print/Online. Copyrights Holder: R., Syahrul, Elfia Sukma, dan Utami Dewi Pramesti. First Publication: Hortatori Jurnal Pendidikan Bahasa dan Sastra Indonesia (2018).

This work is licensed under a Creative Commons Attribution-ShareAlike 4.0 International License.

\section{Pendahuluan}

Karya ilmiah dan inovatif yang paling dekat dengan guru adalah Pelatihan Tindakan Kelas (PTK). PTK merupakan penelitian yang berlatar belakang permasalah yang terjadi di kelas. Karya tulis ilmiah yang ditulis guru diharapkan berasal dari praktik pembelajaran di kelas yang dikemas dalam bentuk penelitian tindakan kelas. Guru diharapkan selalu berproses dalam melaksanakan tugas-tugas pembelajaran. Hal itu berimplikasi pada bagaimana guru mengemas persiapan pembelajaran dengan baik, mulai dari merancang RPP, menganalisis materi ajar, memilih media pembelajaran, merancang dan melaksanakan metode dan teknik pembelajaran, mengelola kelas, merancang dan melaksanakan penilaian dengan tepat, serta mempersiapkan perangkat pembelajaran dengan benar.

Tentunya permasalahan dalam PTK ini benar-benar diketahui dan dikuasai guru. Namun, berdasarkan sebuah penelitian (yang termuat dalam lini masa pendidikan daring Mantra Pendidikan daring 2013), ditemukan permasalahan utama dalam penulisan PTK yang dialami guru-guru, yakni: ... secara umum, permasalahan dalam melaksanakan kegiatan PTK sering berawal dari keterbatasan. Terbatasnya waktu, kemampuan menulis laporan, dan persyaratan keterbatasan saat mengikuti prosedur kenaikan pangkat. Keterbatasan waktu dikaitkan dengan beban mengajar perminggu dan tugas lainnya. Guru yang telah lulus sertifikasi mempunyai beban mengajar tatap muka 24 jam per minggu. Belum lagi tugas tambahan lain di sekolah, tugas administratif dan bimbingan. 
Dalam sumber lain, Trisdiono (2015), menemukan kesulitan guru dalam melaksanakan PTK sebagai berikut.

Analisis kesulitan guru dalam melaksanakan PTK dilakukan terhadap aspek kebahasaan dan aspek kajian teori. Aspek kebahasaan dalam penelitian ini adalah rangkaian kalimat yang disusun guru dalam membuat perangkat pembelajaran dan laporan hasil penelitian. Capaian aspek kebahasan selama penelitian sebagai berikut. Sebanyak 25\% subyek mampu menuliskan kalimat dengan kaidah kalimat lengkap dan kompleks dengan pola S-P-O-K1-K2. Sebanyak 75\% subyek didampingi dalam menganalisis kalimat yang disusunnya. Sebesar 50\% subyek sudah menyusun kalimat dan paragraf dengan bahasa baku, bahasa ilmiah. $50 \%$ subjek diminta membaca contoh penyusunan paragraf dari tulisan orang lain, dan mengidentifikasi ciri-ciri kalimat baku tulisan ilmiah.

Berdasarkan data penelitian tersebut, dapat diketahui bahwa salah satu kesulitan guru dalam menulis PTK adalah bidang kebahasaan yaitu dalam diksi, pembuatan kalimat, dan paragraf yang sesuai dengan kaidah bahasa Indonesia yang baik dan benar. Selain itu, kesulitan lain yang dirasakan guru berkenaan dengan pemahaman akan karya tulis ilmiah terutama tentang PTK yaitu mengenai penemuan masalah yang akan dijadikan judul, membuat rancangan penelitian, format, dan sistematika penulisan PTK.

Lebih lanjut, diperoleh data bahwa sebenarnya teori tentang PTK sudah pernah dibaca dan didengar guru, tetapi saat praktik menuliskannya guru tetap mengalami kesulitan. Oleh karena itu, perlu bimbingan khusus agar guru-guru tersebut dapat memahami PTK sekaligus praktik langsung dalam membuat dan melaksanakan, sampai membuat laporan akhirnya. Berdasarkan permasalahan itulah, dalam pelatihan ini, penulis menggunakan Lembar Kerja Peserta (LPK) untuk membantu guru-guru dalam memahami dan melaksanakan PTK. Selain itu, agar mengotimalkan hasil dari pelatihan, digunakanlah model Paircheck $(P c)$ secara berpasangan (2 orang guru). Dalam kelompok berpasangan ini, guru bisa saling mengoreksi sekaligus berdiskusi terhadap PTK yang dirancang, dilaksanakan, dan dihasilkan. Dalam artikel ini, pertanyaan penelitian ada 2 sebagai berikut.

1. Apa hasil pelatihan penulisan PTK bagi guru-guru SD Negeri air Tawar Barat, Kota Padang?

2. Bagaimana medel $P c$ bermedia LKP dilakukan dalam peltihan penulisan PTK bagi guru-guru SD Negeri Air Tawar Barat, Kota Padang?

\section{Model Paircheck}

Model $P c$ merupakan salah satu tipe dari pembelajaran kooperatif. Faiq (2016) menyatakan bahwa paircheck adalah modifikasi dari tipe think pairs share, yaitu pembelajaran yang diakukan dengan cara siswa atau peserta didik diminta untuk saling cek jawaban atau tanggapan terhadap pertanyaan guru atau pengajar saat berada dalam pasangan. Dalam pembelajaran model ini, kemandirian, kerja sama, tanggung jawab sosial, dan kemampuan memberi nilai siswa sangat dituntut dan dilatih (Huda, 2013: 11)

Senada dengan pendapat tersebut, Sanjaya (2007) menyatakan bahwa pembelajaran $P c$ bertujuan mendalami atau melatih materi yang telah dipelajarinya secara berpasangan (bisa dalam kelompok satu bangku). Dengan adanya pengecekan yang dilakukan oleh peserta pelatihan (dalam hal ini guru-guru) secara berpasangan, diharapkan kemampuan peserta meningkat. Hal ini karena untuk memeriksa tugas temannya, guru-guru harus lebih dulu memahami secara mendalam materi yang dibelajarkan. Selain itu, dengan adanya pengoreksian teman sebangku ini, ketelitian dan kerja sama peserta didik dilatih lebih dalam. Berikut tabel check dalam pelatihan ini. Berilah tanda centang (checklist) pada Format Pengamatan Penulisan Karya Ilmiah berikut. 
Nama Penulis :

Asal Sekolah :

Judul PTK

Tabel 1. Penilaian dan Pengamatan

\begin{tabular}{|c|c|c|c|c|c|c|}
\hline \multirow{2}{*}{$\begin{array}{l}\text { No } \\
\text {. }\end{array}$} & \multirow[t]{2}{*}{ Kriteria Penilaian } & \multicolumn{4}{|c|}{ Pengamatan dan Penilaian } & \multirow[t]{2}{*}{ Catatan } \\
\hline & & $\begin{array}{c}\text { Baik } \\
\text { Sekali }\end{array}$ & Baik & Cukup & Kurang & \\
\hline 1 & $\begin{array}{l}\text { Format Makalah } \\
\text { a. Tata tulis: ukuran kertas, tipografi, } \\
\text { kerapihan ketik, tata letak, jumlah } \\
\text { halaman. } \\
\text { b. Penggunaan Bahasa Indonesia yang baik } \\
\text { dan benar. }\end{array}$ & & & & & \\
\hline 2 & $\begin{array}{l}\text { Kreativitas Gagasan: } \\
\text { a. Kreatif, inovatif dan bermanfaat bagi } \\
\text { masyarakat. } \\
\text { b. Keaslian gagasan } \\
\text { Kejelasan pengungkapan ide, } \\
\text { sistematika pengungkapan ide }\end{array}$ & & & & & \\
\hline 3 & $\begin{array}{l}\text { Topik yang dikemukakan: } \\
\text { a. Kesesuaian judul dengan tema, topik } \\
\text { yang dipilih dan isi karya tulis. } \\
\text { b. Aktualitas topik dan fokus bahasan yang } \\
\text { dipilih }\end{array}$ & & & & & \\
\hline 4 & $\begin{array}{l}\text { Data dan sumber informasi: } \\
\text { a. Kesesuaian informasi dengan acuan yang } \\
\text { digunakan. } \\
\text { b. Keakuratan data dan informasi }\end{array}$ & & & & & \\
\hline 5 & $\begin{array}{l}\text { Analisis, Sintesis, dan Simpulan } \\
\text { a. Kemampuan menganalisis dan } \\
\text { mensintesis. } \\
\text { b. Kemampuan menyimpulkan bahasan. } \\
\text { c. Kemampuan memprediksi dan } \\
\text { mentransfer gagasan untuk dapat } \\
\text { diadopsi. }\end{array}$ & & & & & \\
\hline & Jumlah & & & & & \\
\hline
\end{tabular}

Tabel 2. Tabel Paircheck $(P c)$ Penulisan PTK

\begin{tabular}{|c|l|l|l|c|c|c|}
\hline No. & Sistematika Penulisan & \multicolumn{3}{|c|}{ Catatan } \\
\cline { 3 - 6 } 1 & HALAMAN JUDUL & & Baik Sekali & Cukup & Kurang & \\
\hline 2 & $\begin{array}{l}\text { HALAMAN } \\
\text { PENGESAHAN }\end{array}$ & & & & & \\
\hline
\end{tabular}




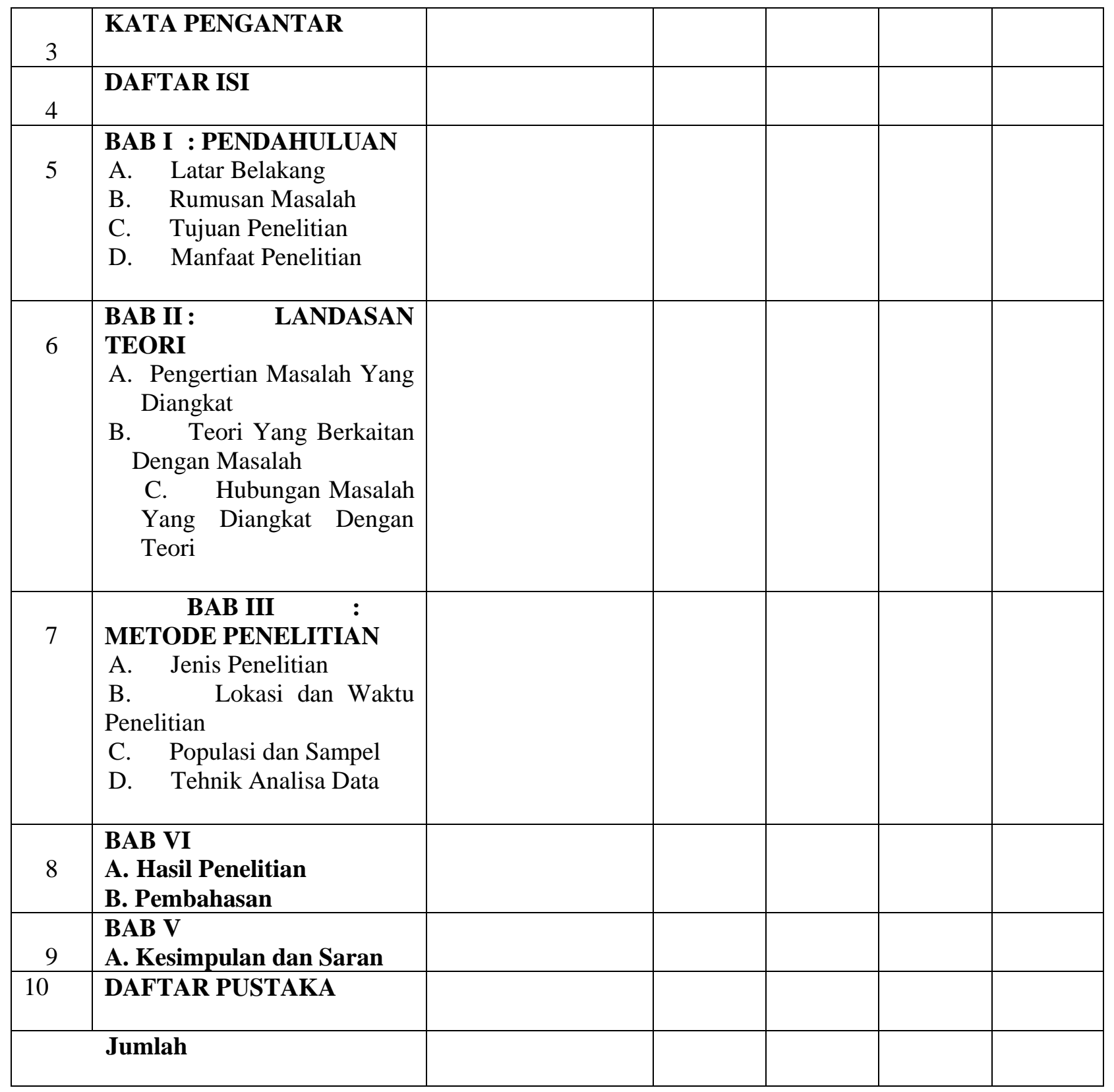

Tabel 3. Tabel $P c$ Penggunaan Bahasa

\begin{tabular}{|c|l|l|l|l|l|l|}
\hline No. & Kebahasan Proposal dan Laporan & \multicolumn{3}{l|}{ Pengamatan dan Penilaian } & \multirow{2}{*}{ Catatan } \\
\cline { 3 - 6 } & \multirow{2}{*}{\begin{tabular}{l} 
PTK \\
\cline { 3 - 6 }
\end{tabular}} & $\begin{array}{c}\text { Baik } \\
\text { Sekali }\end{array}$ & Baik & Cukup & Kurang & \\
\hline 1 & Penulisan Ejaan & & & & & \\
\hline 2 & Penggunaan Diksi & & & & & \\
\hline 3 & Kebakuan kalimat & & & & & \\
\hline 4 & Kekoherensian Pargaraf & & & & & \\
\hline 5 & Kekofesifan Paragraf & & & & & \\
\hline Jumlah & & & & & \\
\hline
\end{tabular}

Keterangan: 


$\begin{array}{ll}\text { Baik sekali } & \text { : Ditemukan kurang dari } 2 \text { kesalah } \\ \text { Baik } & \text { : Ditemukan lebih dari } 3 \text { sampai } 5 \text { kesalahan } \\ \text { Cukup } & \text { : Dutemukan } 6 \text { sampai } 9 \\ \text { Kurang } & \text { : Ditemukan lebih dari } 10 \text { kesalahan }\end{array}$

\section{Lembar Kerja Peserta Pelatihan (LKP)}

Lembar Kerja Peserta Pelatihan (LKP) adalah modifikasi dari Lembar Kerja Siswa (LKS). Bedanya, LKPP diperuntukkan bagi peserta pelatihan atau dalam hal ini adalah guru-guru sekolah dasar. Oleh karena itu, prinsip LKPP sama dengan LKS.

Menurut Hidayah (2007: 8), LKS dibuat pengajar berupa unsur-unsur penulisan media grafis, hierarki materi dan pemilihan pertanyaan-pertanyaan sebagai stimulus yang efisien dan efektif untuk menarik perhatian peserta didik. Melalui LKS, guru atau pengajar dapat membimbing peserta didik untuk menjawab soal-soal atau latihan-latihan yang telah tersedia setelah menaikkan materi pokok tertentu.

Menurut Darmodjo dan JennyKaligis (1992: 40) dalam Salirawati (2017), LKS atau Lembar Kerja Siswa merupakan sarana pembelajaran yang dapat digunakan guru dalam meningkatkan keterlibatan atau aktivitas siswa dalam proses belajar-mengajar. Pada umumnya, LKS berisi petunjuk praktikum, percobaan yang bisa dilakukan di rumah, materi untuk diskusi, Teka Teki Silang, tugas portofolio, dan soal-soal latihan, maupun segala bentuk petunjuk yang mampu mengajak siswa beraktivitas dalam proses pembelajaran. Hal ini sejalan dengan pedapat Nadlah (2002) yang menyatakan, "Salah satu penunjang sarana pembelajaran yang dapat digunak-an untuk mengeksplorasi lingkungan adalah Lembar Kegiatan Siswa (LKS)."

Penggunaan media LKS ini pun memiliki manfaat. Arsyad (2005) menyatakan manfaat LKS antara lain sebagai berikut.

1. Memperjelas penyajian pesan dan informasi sehingga proses belajar semakin lancar dan dapat meningkatkan hasil belajar.

2. Meningkatkan motivasi siswa dengan mengarahkan perhatian siswa, sehingga memungkinkan siswa belajar sendiri sesuai dengan kemampuan dan minatnya.

3. Penggunaan media dapat mengatasi keterbatasan indera, ruang, dan waktu.

Mengacu pada defenisi dan manfaat penggunaan LKS tersebut, secara umum LKP dalam penelitian ini pun berisi rangkuman materi yang berkenaan dengan PTK dan disertai pula dengan latihan-latihan soal serta langkah-langkah praktis untuk menyusun PTK, mulai dari menemukan masalah, melaksanakan, sampai membuat laporan akhir. Dengan LPK ini, guru-guru dapat menggali lebih dalam segala kendala atau masalah dalam lingkungan kerjanya yang tidak lain adalah kelas yang diajar untuk kemudian dicari cara penyelesaiannya dengan tujuan peningkatan kulitas pembelajaran. Melalui LPK ini diharapkan lebih memudahkan guru-guru dalam memahami dan melaksanakan PTK karena dengan mengikuti tahap demi tahap materi, latihan, dan petunjuk praktik sebenarnya guru diarahkan menyusun PTK yang baik.

\section{Metode}

Pendekatan penulisan artikel ini adalah kualitatif dengan metode deskriptif. Subjek penelitian adalah 26 guru SD Negeri 16, 26, dan 28 Air Tawar Timur -Kota Padang seabagai peserta pelatihan. Instrumen utama dalam penelitian ini adalah peneliti sendiri dan dibantu instrumen lain yaitu tes keterampilan menulis PTK dan lembar observasi. Penulis menyajikan hasil pretes dan postes keterampilan menulis PTK oleh 26 guru SD Negeri 16, 26, dan 28 Air Tawar Timur Kota Padang. Selain itu, penulis juga menjelaskan bagaimana yaitu model Pc bermedia LPK digunakan dalam pelatihan. 


\section{Hasil dan Diskusi}

Setelah dilakukan pelatihan penulisan PTK, berikul hasil nilai para peserta

Tabel 1. Tabel Nilai Keterampilan Menulis PTK

\begin{tabular}{|c|c|r|r|r|r|}
\hline \multirow{2}{*}{ Interval } & \multirow{2}{*}{ Tingkat } & \multicolumn{2}{|c|}{ Pretest } & \multicolumn{2}{|c|}{ Postest } \\
\cline { 3 - 6 } & & Frekuensi & \multicolumn{1}{|c|}{ Persentase } & Frekuensi & \multicolumn{1}{c|}{ Persentase } \\
\hline $81-100$ & Baik Sekali & 0 & 0 & 6 & 23,1 \\
\hline $66-80$ & Baik & 0 & 0 & 6 & 23,1 \\
\hline $56-65$ & Cukup & 2 & 7,69 & 14 & 53,8 \\
\hline $41-55$ & Kurang & 8 & 30,77 & 0 & 0 \\
\hline$<41$ & Buruk & 16 & 61,54 & 0 & 0 \\
\hline
\end{tabular}

Secara keseluruahan keterampilan menulis PTK guru-guru mengalami perubahan yang positif ditandai dengan adanya peningkatan nilai rata-rata pada postes. Secara lengkap peningkatan keterampilan menulis PTK guru sebagai berikut.

Grafik 1. Peningkatan Keterampilan Menulis PTK oleh Guru

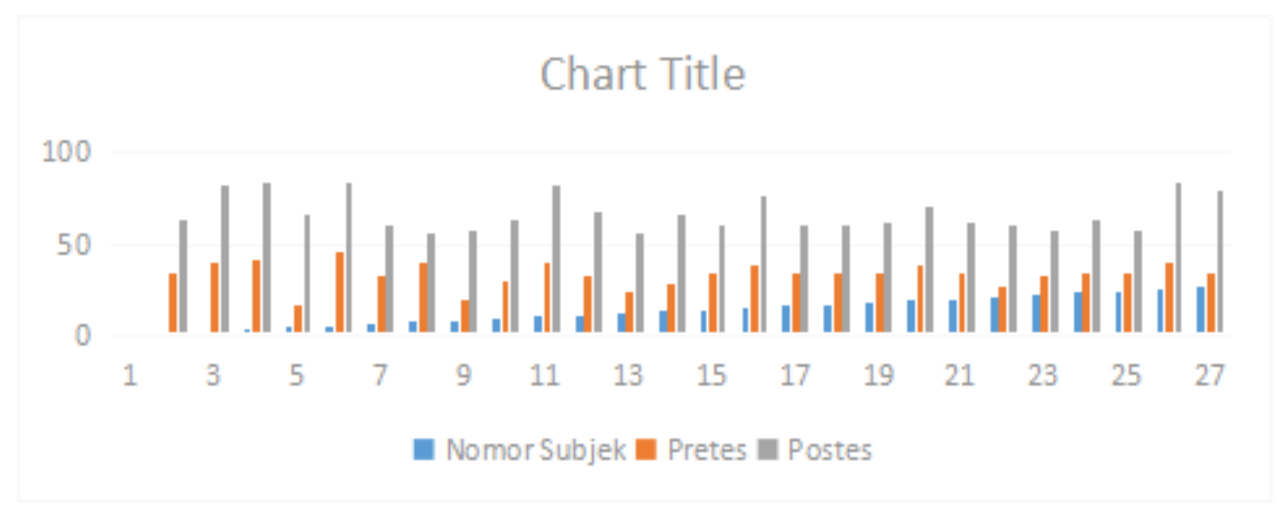

\section{Pelaksanaan Model Pc Bermedia LKPP dalam Pelatihan Penulisan Karya Tulis Ilmiah Berbahasa Indonesia dan Penelitian Tindakan Kelas}

Kegiatan pelatihan Pelaksanaan Pelatihan Tindakan Kelas (PTK) bagi Guru-Guru SDN 16, SDN 26, dan SDN 28 Air Tawar Timur, Kota Padang Sumatera Barat" dilaksanakan dalam empat kali pertemuan. Pertemuan pertama dan kedua dilakukan untuk membahas proposal penelitian yang telah dibuat, sedangkan pertemuan ketiga untuk membahas pelaksanaan PTK, dan pertemuan ketiga membahas laporan pelaksanaan PTK. Sebelum dilakukan pelatihan, guru-guru telah mendapatkan LKP dan mencoba mengisinya sesuai dengan pengetahuan dan pemahaman masing-masing. Guru-guru membawa LPK yang telah diisi dan proposal PTK yang telah dibuat.

\section{Pelaksanaan Hari Pertama}

Setelah acara pembukaan selesai, dilanjutkan sesi prestes. Pretes adalah tes yang dilakukan untuk mengetahui pengetahuan, pemahaman, dan kemampuan awal peserta sebelum diadakan pelatihan. Pretes berisi soal pilihan ganda sebanyak 50 buah dengan empat pilihan jawaban. Komposisi soal pretes yakni 70\% soal tentang PTK dan $30 \%$ soal tentang penulisan karya tulis ilmiah bahasa Indonesia. Waktu mengerjakan pretes selama 60 menit atau 1 jam.

Setelah pretes, guru-guru mengikuti sesi pertama. Materi sesi pertama berkenaan dengan "Penelitian Tindakan Kelas atau Action Research". Pada sesi kedua ini, pemateri langsung membentuk guru-guru menjadi kelompok berpasangan. Selanjutnya, pelatihan dilakukan melalui metode diskusi dan 
tanya jawab. Setiap guru dalam kelompok secara silang mengoreksi isian LPK yang dibuat temannya melalui tabel $P c$.

Sebelum melakukan diskusi, terlebih dahulu guru-guru diberikan bahan atau materi pelatihan yang berkenaan dengan PTK. Pemberian materi pertama ini dilakukan melalui metode diskusi atau tanya jawab awal yang berkaitan dengan pengalaman guru-guru tersebut dalam melakukan PTK. Hal ini dilakukan dengan cara tanya jawab berdiskusi melalui bahan berupa Lembar Kerja Peserta (LPK). LPK diisi peserta sebelum pelatihan ini berlangsung. Jadi, saat pelatihan LPK masing-masing guru tersebut dikoreksi dan diperbaiki.

Melalui LPK tersebut, terjadilah diskusi dan penyempurnaan proposal PTK. Setiap guru mengangkat permasalahan di kelas masing-masing. Permasalahan tersebut meliputi (1) minat membaca siswa yang rendah, (2) kesulitan siswa memahami teori atau hapalan, seperti dalam mata pelajaran sejarah, (3) rendahnya ketelitian siswa saat menulis, (4) kesulitan siswa membaca Alquran, dll.

Pembahasan proposal dilakukan satu per satu bagian mulai dari penemuan masalah dan solusi penanganannya. Pada saat itu, didapat fakta bahwa ternyata guru sulit merumuskan permasalahan penelitian dari berbagai masalah yang ditemukan di kelas bahkan guru merasa lebih sulit dalam merumuskan judul penelitian. Kesulitan guru dalam merumuskan masalah dan penentuan judul penelitian tersebut di antaranya karena hal-hal berikut:

(1) masalah yang ditemui guru sering kali bukan permasalahan pembelajaran, tetapi lebih pada masalah sarana dan prasana, seperti ketersedian alat olahraga, tersedianya infokus, dan lain-lain.

(2) pengetahuan guru mengenai model, teknik, dan metode mengajar masih kurang.

(3) perumusan pertanyaan dan judul sering kali ambigu (tidak jelas).

Untuk membantu menjawab pertanyaan dan kesulitan guru, pemateri menampilkan bahan dan contoh langsung yang berkaitan erat dengan kelas serta pembelajarannnya. Misalnya, ketika seorang guru menjelaskan permasalahannya saat mengajar "Sejarah Kerajaan Hindu, Budha, dan Islam" karena siswa tidak mampu menghapal (ada pula yang malas), pelatih langsung menampilkan berbagai artikel dalam jurnal yang terkait. Lalu mendiskusikan berbagai artikel tersebut kemudian mengaitkan dan menyesuaikannya dengan situasi dan kondisi sekolahnya. Dengan penjelasan tersebut, diharapkan memperluas wawasan dan pengetahuan guru-guru peserta pelatihan.

\section{Pelaksanaan Hari Kedua}

Pelatihan hari kedua diisi dengan pemberian materi lanjutan PTK dan materi penggunaan bahasa dalam karyatulis ilmiah. Sesi pertama tentang PTK bertujuan untuk memantapkan proposal PTK yang dibuat guru agar sesuai dengan ketentuan sehingga tepat ketika akan dilaksanakan. Seluruh peserta berkesempatan untuk memaparkan rancangan proposal PTK-nya. Peserta pun diberikan kesempatan untuk bertanya berkaitan dengan rancangan proposalnya tersebut.

Sembari menyimak penjelasan pemateri, peserta diperkenankan langsung memperbaiki bahkan mengembangkan rancangan proposalnya tersebut menjadi sebuah proposal utuh yang terdiri atas halaman judul, bab I (pendahuluan), bab II (kajian pustaka), dan bab III (metodologi penelitian).

Permasalahan yang muncul setelah itu adalah peserta masih keliru dalam menyusun perumusan atau pertanyaan penelitian. Dari 26 rancangan proposal yang dikumpulkan hanya 6 peserta yang telah tepat dalam membuat pertanyaan penelitian ini. Selebihnya peserta masih keliru dalam menyusun pertanyaan penelitian tersebut. Kesalahan ini meliputi (1) ketidaksesuaian antarlatar belakang dan perumusan masalah, (2) pertanyaan penelitian dibuat dalam bentuk pernyataan atau kalimat berita, (3) kata tanya yang masih menggunakan kata pengaruh dan hubungan, dan (4) bahkan ada beberapa yang belum menyantumkan pertanyaan penelitian ini. Kekeliruan selanjutnya adalah ketidaksesuaian pertanyaan penelitian dengan tujuan penelitiannya. Misalnya, dalam pertanyaan masalah "Bagaimanakah penerapan metode jaritmatika dapat meningkatan kemampuan menghapal perkalian Ddsar sampai dengan 10X10 melalui kepada siswa kelas 6 Sekolah Dasar Negeri 16 Air Tawar Timur Kota Padang?", tujuan penelitian yang ditulis peserta tersebut adalah "Untuk mempermudah guru dalam mengajar matematika dalam materi perkalian 10X10." Tentu jawaban ini tidak sesuai dengan pertanyaan penelitian yang dihasilkan. Perbaikan tujuan penelitian tersebut seharusnya yaitu "Menjelaskan metode jaritmatika digunkan untuk meningkatkan kemempuan menghapal perkalian dasar 10X10." 
Pada sesi materi kedua berkenaan dengan "Penulisan Karya Tulis Ilmiah". Hampir serupa dengan sesi pertama tentang PTK, pemberian materi sesi kedua ini juga berbantuan media LKP (Lembar Kerja Peserta). Pada lembar kerja ini, disajikan teori-teori sekaligus latihan yang secara langsung bisa dikerjakan peserta. Namun, bagian awal penyajian, pemateri mengajak peserta untuk mengecek rancangan proposal PTK masing-masing yang berkenaan ejaan, pilihan kata, keefektifan kalimat, dan sistematika penulisan, penomoran, penulisan kutipan dan daftar teori. Dari hasil membacaan intensif ini, ditemukan masih banyak kesalahan berkenaan hal-hal tersebut. Kesalahan terbesar berkenaan dengan kebakuan dan keefektifan kalimat yang dibuat. Contoh kesalahan yang ditemui dari rancangan proposal peserta di antaranya sebagai berikut.

(1) Bab I ini menjelaskan latar belakang masalah, pertanyaan penelitian, dan tujuan penelitian.

(2) Penelitian ini bertujuan untuk meningkatkan hasil belajar para siswa-siswa SDN 16 Air Tawar Timur Kota Padang.

(3) Karena minat membaca siswa rendah, maka kami mengusulkan proposal ini.

Kalimat perbaikan kalimat-kalimat tersebut sebagai berikut.

(1) a. Dalam bab I ini dijelaskan mengenai latar belakang masalah, pertanyaan penelitian, dan tujuan penelitian.

(1) b. Pada bab I ini Penulis menjelaskan latar belakang masalah, pertanyaan penelitian, dan tujuan penelitian.

(2) a. Penelitian ini bertujuan meningkatkan hasil belajar siswa SDN 16 Air Tawar Timur Kota Padang.

(3) a. Karena minat membaca siswa rendah, kami mengusulkan proposal ini.

Tahap akhir pertemuan ini adalah masingmasing guru memberikan penilaian dan catatan terhadap proposal yang telah dibuat oleh teman sekelompoknya.

\section{Pelaksanaan Hari Ketiga}

Pelatihan hari ketiga dilakukan dengan jarak tiga Minggu dari pertemuan pertama. Hal ini dimaksudkan agar guru dapat mepraktikan PTK secara maksimal di kelas. Pelatihan hari ketiga diisi dengan materi pembahasan pelaksanaan penelitian yang telah dilakukan oleh guru di kelas dan megubahnya menjadi laporan penelitian yang mengisi Bab IV atau Hasil dan Pembahasan penelitian. Setiap peserta menampilkan laporan pelaksanaan kegiatan. Berbagai hal yang masih kurang atau keliru dari laporan penelitian guru langsung diperbaiki.

LPK yang telah diisi guru berkenaan dengan pelaksanaan PTK di kelas selanjutnya didiskusikan secara dalam kelompok berpasangan melalui model $P c$. Setiap guru mengoreksi secara silang kelengkapan dan ketepatan laporan PTK yang masih dalam format di LPK. Bagian yang dikoreksi adalah kelengkapan laporan (hasil atau temuan penelitian dan pembahasannya), penggunaan bahasa, dan kelengkap format.

\section{Pelaksanaan Hari Keempat}

Pelatihan hari keempat berisi pembahasan singkat mengenai laporan PTK utuh yang dibuat oleh masing-masing guru berdasarkan isian pada LPK-nya. Setiap guru (peserta) mempresentasikan laporan PTK yang dibuat. Pemateri dan peserta lain menyimak dan memberikan masukan serta arahan pada bagianbagian yang kurang tepat. Pemateri juga memberikan kiat singkat untuk mengubah laporan PTK menjadi artikel.

Pelatihan hari keempat juga diisi dengan postes. Postes dilakukan untuk mengetahui kemajuan pemahaman dan keterampilan menulis PTK guru.

\section{Simpulan}

Setelah dilakukan peletihan, dapat disimpulkan beberapa hal berikut. Pertama, dari hasil pretes dan postes menunjukkan pelatihan PTK pada guru-guru SD Negeri 16, 26, dan 28 Air Tawar Timur menunjukkan peningkatan. Hal ini ditandai melalui peningkatan nilai rerata PTK oleh guru. Kedua, pelatihan PTK melalui model Pc bermedia LPK diterapkan pada setiap pertemuan. Hal ini dengan melibatkan guru untuk praktik langsung menulis proposal dan laporan (sementara) PTK dalam LPK yang selanjutnya diubah bentuk dalam laporan utuh. Model dan media ini membuat guru lebih terbimbing dalam 
melakukan PTK sekaligus dapat membina kolaborasi antarguru. Berdasarkan hal ini, dapat diketahui Pc bermedia LPK dapat membantu guru dalam membuat PTK.

\section{Ucapan Terima Kasih}

Penulis mengucapkan terima kasih kepada kepada sekolah dan guru-guru SD Negeri 16, 26, serta 28 Air Tawar Timur Kota Padang yang telah berperan aktif dalam mengikuti pelatihan. Ucapan terima kasih juga penulis tujukan kepada Kepala UPTD. Kecamatan Padang Utara, Bapak Saringat, S.Pd. atas bantuan dan dukungannya sehingga kegiatan pelatihan berjalan sukses dan bermanfaat.

\section{Daftar Rujukan}

Arsyad, Azhar. Media Pembelajaran. Jakarta: Raja Grafindo Persada, 2005. Print.

Departemen Pendidikan dan Kebudayaan Direktorat Jendral Pendidikan Dasar dan Menengah Direktorat Pendidikan Menengah Umum. Penelitian Tindakan (Action Research). Jakarta: Departemen Pendidikan dan Kebudayaan Direktorat Jendral Pendidikan Dasar dan Menengah Direktorat Pendidikan Menengah Umum, 1999. Print.

Faiq, M. "Mengimplementasi Model Pembelajaran Kooratif Tipe Two Stay Two Stray". Diunduh http://penelitiantindakankelas.blogspot.com/2013/03/ modelpembelajarankooperatif-two-stay-twostray.html?m=1. Diakses 20 November 2017. Web. 24 April 2016.

Huda, M. Cooperative Learning. Yogyakarta: Pustaka Pelajar, 2013. Print

Mantra Pendidikan. "Permasalahan Guru dalam Melaksanakan PTK dan Alternatif Solusinya". (daring). Diunduh dari http://www.matrapendidikan.com/2016/10/ permasalahan-guru-dalam-ptk-dan.html. Diakses 12 April 2017). Web. 2013.

Nadlah, Izzun. "Analisis Lembar Kerja Siswa (LKS Biologi Karya MGMP di Kota Semarang yang Digunakan Siswa Kelas Vii Semester Gasal 2010 /2011”. Jurnal PHENOMENON Volume 2 nomor 1 20012. journal.walisongo.ac.id/index.php/Phenomenon/article/viewFile/424/388. Web. 2012.

Salirawati. "Penyusunan dan Kegunaan LKS dalam Pembelajaran". Diunduh dari http://webcache.googleusercontent.com/search?q=cache:RPkPAfNjHq8J:staffnew.uny.ac.id/uplo $\mathrm{ad} / 132001805 /$ pengabdian/19penyusunnan-dan-kegunaanlks.pdf $+\& \mathrm{~cd}=2 \& \mathrm{hl}=\mathrm{id} \& \mathrm{ct}=\mathrm{clnk} \& \mathrm{gl}=\mathrm{id}$. Diakses 10 Februari 2018.

Suparno, 1998. "Penggunaan Bahasa Indonesia dalam Tulisan llmiah". Makalah disajikan pada SeminarLokakarya Penyuntingan Jurnal Angkatan IV IKIP Malang, tanggal 13-16 Januari 1998.

Trisdiono, Harli. "Analisis Kesulitan Guru dalam Melaksanakan Penelitian Tindakan Kelas". (daring). (Dikutip dari http://lpmpjogja.org/wp-content/uploads/2015/07/). Diunduh 12 April 2017). Web. 2014.

Wardani, I.G.A.K. Teknik Menulis Karya Ilmiah. Jakarta: Universitas Terbuka, 2007. Print. 